\title{
p21 Gene Expression Evaluation in Esophageal Cancer Patients
}

\author{
Tahereh Salari Fanoodi ${ }^{a} \quad$ Gholamreza Motalleb ${ }^{b, c}$ \\ Ahmad Yegane Moghadam ${ }^{d}$ Rezvan Talaee ${ }^{e}$ \\ ${ }^{a}$ Department of Biology, Faculty of Sciences, Campus University of Zabol, b Department of \\ Biology, Faculty of Sciences, and ' Center of Agricultural Biotechnology, University of Zabol, \\ Zabol, and Departments of ${ }^{\mathrm{d}}$ Otolaryngology and ${ }^{\mathrm{e}}$ Dermatology, Kashan University of \\ Medical Sciences, Kashan, Iran
}

\author{
Key Words \\ Esophageal cancer · Gene expression · Paraffin-embedded tissue · p21 · RT-qPCR
}

\begin{abstract}
Background: Cancer is the third most common cause of death in Iran, and 30,000 Iranians lose their lives each year due to cancer. Esophageal cancer is the eighth most common cancer and the sixth leading cause of death from cancer worldwide. It is reported that more than $80 \%$ of all deaths from esophageal cancer occur in developing countries. The p21 protein is encoded by WAF1/CIP1, a tumor suppressor gene located on chromosome 2.6 p21. This protein is known to be related to the cell cycle; 221 stimulation is a common mechanism of growth inhibition in different physiological conditions. Summary: The results indicated no significant difference in p21 gene expression between patients and controls $(p>0.05)$. Moreover, no significant difference was observed in p21 gene expression between males and females ( $p>$ 0.05). Key Message: It appears that p21 is not a specific tumor marker in Iranian esophageal cancer patients. Practical Implications: In this qualitative research work, for the first time, we investigated the p21 gene expression in esophageal cancer patients in Iran. For the present study, we randomly selected 15 paraffin-embedded esophageal cancer tissues and 15 paraffin-embedded normal esophageal samples collected from different medical centers in Zahedan and Kashan. RT-qPCR reactions were performed with three repetitions for the p21 gene and internal control (GAPDH) using the $2^{-\triangle \Delta C t}$ (Livak) method for all samples. Results were analyzed using SPSS software.




\section{Introduction}

Cancer is the second most common cause of death in the United States and the third most common in Iran; 30,000 Iranians lose their lives to cancer each year [1]. Esophageal cancer is the eighth most common cancer and the sixth leading cause of death from cancer worldwide. It is reported that more than $80 \%$ of all deaths from esophageal cancer occur in developing countries. Squamous cell carcinoma (SCC) is responsible for more than $90 \%$ of esophageal cancer cases in the United States. Esophageal cancer incidence varies significantly according to geography and race, which can be due to differences in exposure to risk factors [2]. SCC accounts for $90 \%$ of esophageal cancers in countries on the esophageal cancer band (from East Turkey across northern Iran and the Central Asian republics to northern and central China) [3, 4]. Iranian studies indicate a high risk of esophageal cancer in the coastal areas of the Caspian Sea (northern Iran, Golestan) [5], while the risk of esophageal SCC (ESCC) is more or less constant [6].

The $\mathrm{p} 21$ protein is encoded by WAF1/CIP1 [part 1 of wild-type $p 53 /$ protein 1 reactive to cyclin-dependent kinase (CDK)], a tumor suppressor gene located on chromosome 2.6p21 [7]. This protein is known to be related to the cell cycle; $p 21$ stimulation is a common mechanism of growth inhibition in different physiological conditions. p21 is observed in aging courses, or in genes involved in diseases associated with aging (Alzheimer's disease, amyloidosis); reversible and irreversible forms of growth inhibition due to damage and final differentiation to postmitotic cells are stimulated shortly and transiently [8-10]. p21 primarily prevents the progression of the cell cycle by preventing CDK2 activity, which is required for the phosphorylation of retinoblastoma with sequential release and gene activity associated with E2F, the burning of duplicated sources, and the activity of proteins involved in the synthesis of DNA [11]. This activity is also shared with other inhibitors such as P27 and P57; genetic and biochemical evidence suggests that CDK2 plays certain roles in the appearance of tumors [12]. However, $p 21$ is exclusively placed for acting as an inhibitor, which is active in response to cell tissue varieties and environmental signals to develop tumor suppressor activity. Experimental evidence suggests that the proliferation of human cancer cells does not require CDK2 activity [13]. Various immunohistochemical studies have investigated $p 21$ in different tumors. Some studies have shown a relationship between $p 21$ expression and worse prognosis in breast cancer [14], but it has been proven to be less likely to cause worse prognoses in anal [15], bladder [16], and ovarian [17] cancers. The association between the expression of $p 53, p 21, \mathrm{MDM} 2$, and P16 proteins and p21 gene polymorphisms and gene methylation of $P 16$ in esophageal tumor tissue was assessed in patients living in northeast Golestan province. Results revealed an association between smoking in people with cancer and $p 53$ protein expression and polymorphism of the p21 gene [18]. A similar study of the relationship between $p 53$ and $p 21$ and smoking associated the overexpression of $p 21$ with poor prognosis by immunohistochemistry [19]. A study of p21 polymorphism in esophageal cancer and its relationship to smoking showed that two polymorphisms of $p 21$, alone or mixed, are not biomarkers of a genetic predisposition to ESCC [18]. Thus, research findings suggestive of an interaction between environmental factors such as smoking and genetics and molecular mechanisms like methylation of the $p 16$ gene show the polymorphism of the $\mathrm{p} 21$ gene and increased $p 53$ protein expression.

\section{Materials and Methods}

Paraffin-embedded tissue was sectioned by a microtome device, and slices were placed in 1.5-mm sterile RNase-free tubes. After removing the paraffin, RNA was extracted from the paraffinic tissue by the RNeasy ${ }^{\circledR}$ FFPE Kit (QIAGEN Company) (table 1).

After removing the paraffin, RNA was extracted as described below [20]. First, $240 \mu$ l proteinase K digestion buffer was added to the tube and vortexed for 1 min at a speed of 10,000 rpm. Then, $10 \mathrm{ml}$ proteinase 


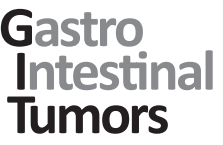

Table 1. List of RNA extraction kit components

\begin{tabular}{l|l}
\hline Gastrointest Tumors 2015;2:144-164 \\
\hline DOI: 10.1159/000441901 & $\begin{array}{l}\text { (c) 2015 S. Karger AG, Basel } \\
\text { www.karger.com/gat }\end{array}$ \\
\hline Salari Fanoodi et al.: p21 Gene Expression Evaluation in Esophageal Cancer Patients
\end{tabular}

\begin{tabular}{lc}
\hline Buffer PKD & $45 \mathrm{ml}$ \\
Buffer RBC & $15 \mathrm{ml}$ \\
Buffer RPE & $11 \mathrm{ml}$ \\
K proteinase & $1.25 \mathrm{ml}$ \\
RNase 0-free Dnase I & $1,500 \mathrm{U}$ \\
RNase 0-free water & $12.5 \mathrm{ml}$ \\
DNase Booster Buffer & $2 \mathrm{ml}$ \\
RNeasy MinElute spin columns & \\
$\quad$ & 50 parts \\
\hline & \\
& \\
\hline & each in a 2-ml collection tube) \\
PNA kit components & $20 \mathrm{reactions}$ \\
Water, nuclease-free & $25 \mu \mathrm{l}$ \\
$5 \times$ reaction buffer & $2 \times 1.25 \mathrm{ml}$ \\
Ribolock RNase Inhibitor $(20 \mathrm{U} / \mu \mathrm{l})$ & $150 \mu \mathrm{l}$ \\
10 mM dNTP Mix & $25 \mu \mathrm{l}$ \\
RevertAid M-MuLV RT $(200 \mathrm{U} / \mu \mathrm{l})$ & $50 \mu \mathrm{l}$ \\
\hline
\end{tabular}

Table 2. List of cDNA kit components

$\mathrm{K}$ was added and mixed gently by pipetting. The mixture was incubated for $15 \mathrm{~min}$ at $56^{\circ} \mathrm{C}$ and then placed at $80^{\circ} \mathrm{C}$ for $15 \mathrm{~min}$. In the next stage, the mixture was centrifuged lightly, and the colorless lower phase was transferred to a new 1.5-mm tube. Tubes containing the samples were incubated on ice for $3 \mathrm{~min}$ and then centrifuged for $15 \mathrm{~min}$ at a speed of 135,000 rpm. In the next stage, the supernatant solution was transferred into a new 2-ml tube without damaging the deposit. No precipitation was transferred. Then, all DNase Booster Buffer samples (about $25 \mu \mathrm{l}$ ) and $10 \mu \mathrm{l}$ DNasel were added based on a 1/10 ratio. The mixture was mixed well by inverting the tubes and centrifuging at low speed for a short time (spinning), so that the surrounding fluid was placed at the end of the tube, and then it was incubated at room temperature for 15 min. Next, 500 $\mu \mathrm{l}$ RBC buffer was added and thoroughly mixed followed by the addition of 1,200 $\mu \mathrm{l} 96-100 \%$ ethanol. The mixture was mixed well by pipetting and then immediately entered into the next phase of washing. Subsequently, $700 \mu$ l of the sample was transferred to RNeasy MinElute ${ }^{\circledR}$ Spin Columns placed in a 2-ml tube; the door was slowly shut, and the sample was centrifuged for $15 \mathrm{~s}$ at a speed of 12,000 rpm. The solution inside the tubes was discarded, and the tubes were used again at a later stage. The previous stage was repeated until all samples had passed through the RNeasy MinElute Spin Columns. Then, $500 \mu \mathrm{l}$ buffer was added to the RNeasy MinElute Spin Columns, the doors were slowly closed, and the buffer was centrifuged for $15 \mathrm{~s}$ at a speed of 12,000 rpm. The solution inside the tube was discarded, and the tubes were used again at a later stage. Next, $500 \mu$ l buffer was added to the RNeasy MinElute Spin Columns, the doors were slowly closed, and the buffer was centrifuged for $2 \mathrm{~min}$ at a speed of 10,000 rpm so that the RNeasy MinElute Spin Columns could be washed (the tubes and the solution inside the tubes were discarded). After centrifugation, the RNeasy MinElute Spin Columns were removed from the tube so that they did not touch the inferior solution and were placed in new tubes; the RNeasy MinElute Spin Column doors were left open, and the solution was centrifuged at maximum speed for $5 \mathrm{~min}$ (the tubes and solution inside the tubes were discarded). Finally, RNeasy MinElute Spin Columns were placed on the walls of new 1.5-ml tubes, $30 \mu$ RNase-free water was added directly to the walls, and the doors were gently closed. The solution was incubated for 10 min at room temperature and then centrifuged for 1 min at maximum speed until RNA was extracted. To ensure the quality and quantity of the extracted RNA, concentration and OD were measured by optical spectroscopy, and samples were observed on 2\% agarose gel. In the second stage after RNA extraction, DNA was synthesized from it for the next stages. This reaction was performed using the First Strand cDNA Synthesis Kit (K1621; Fermentas Thermo Scientific) (table 2) as detailed below.

Before beginning the tests, all materials in the kit were mixed and centrifuged. Then, all ingredients were placed on ice; $0.1-5 \mu \mathrm{l}$ of RNA was extracted and increased to $12 \mu \mathrm{l}$ by adding sterile distilled water (water, nuclease free). In the next stage, tubes were placed at $65^{\circ} \mathrm{C}$ for $5 \mathrm{~min}$ and then placed on dry ice; $4 \mu \mathrm{l}$ of reaction buffer was added, and then $1 \mu \mathrm{l}$ of reagent Ribolock RNase Inhibitor (20 U/ $\mu \mathrm{l}$ ) was added. Two microliters of $10 \mathrm{mM}$ dNTP and $1 \mu \mathrm{l}$ of RevertAid M-MuLVRT (20 U/ $\mu \mathrm{l}$ ) were added. The volume inside the tube, $20 \mu \mathrm{l}$, was mixed, centrifuged, and then placed at $42^{\circ} \mathrm{C}$ for $60 \mathrm{~min}$. Then, samples were placed at $70^{\circ} \mathrm{C}$ 


\section{Gastro \\ Intestinal \\ Tumors}

Table 3. Characteristics of the P21 gene primers

Table 4. Characteristics of the reference gene GAPDH primer

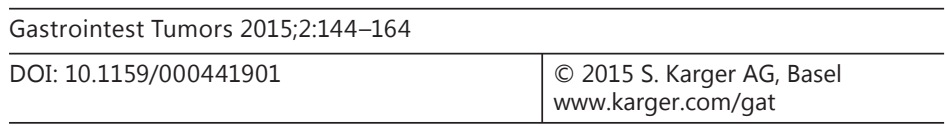

\begin{tabular}{ll} 
Forward primer & Reverse primer \\
\hline GACCAGCATGACAGATTTC & TGAGACTAAGGCAGAAGATG \\
GC $\%=47.37$ & GC $\%=45.00$ \\
TM: 53.8 & TM: 54.2 \\
\hline
\end{tabular}

\begin{tabular}{ll}
\hline Reverse primer & Forward primer \\
\hline CATGTAGTTGAGGTCAATGAAGG & GAGCCACATCGCTCAGACAC \\
TM: 58 & TM: 58 \\
\hline
\end{tabular}

for $5 \mathrm{~min}$ and finally kept at $-20^{\circ} \mathrm{C}$. Then, cDNA, obtained to quantify gene expression, was assessed by RT-qPCR. For this reaction, the mRNA sequences of the p21 gene were designed according to the primer sequence.

\section{Stages of Real-Time PCR Reaction}

The characteristics of the p21 gene sequence are as follows: locus: NM_000389; linear: PRI 25-MAY2014 Homo sapiens CDK inhibitor 1A (p21, Cip1; CDKN1A), transcript variant 1, mRNA (table 3).

To determine the optimal amount of cDNA, concentrations were prepared at 100,200, 300, 400, and 500 ng. In this test, the Cinagen HotTaq Evagreen qPCR was used. After determining the optimum amount of cDNA, the amounts of mixture and components for real-time PCR reaction for $p 21$ and glyceraldehyde-3-phosphate dehydrogenase (GAPDH) primers (table 4) were prepared as described below. Real-time qPCR reaction was performed to compare p21 gene expression. GAPDH was used as an internal control. The temperature of $54^{\circ} \mathrm{C}$ was selected, and the results were evaluated. For the standard curve, several serial dilutions of one sample were prepared for both primers and the reaction by QIAGENE USA Rotorgen, and then the standard curve was drawn by the software, and the reaction output was calculated. To ensure accuracy in sample size, samples were placed on agarose gel. Statistical analysis was performed by the t test and SPSS16 software.

\section{Results}

Fifteen patients with esophageal cancer and 15 healthy subjects were enrolled in the study. Patient samples were taken and matched with the control group regarding gender. Nine participants were male and 6 were female. The control group comprised 15 participants, 9 of whom were men and 6 were women (fig. 1).

\section{RNA Extraction}

The quality of the RNA samples on agarose gel was examined; since RNA was extracted from paraffin-embedded tissue and did not have a high quality, the RNA band can be seen as a smear on the gel (fig. 2). After RNA extraction, the absorption ratio of light at a wavelength of 260-280 $\mathrm{nm}$ was used to determine purity, and the absorption ratio at $260 \mathrm{~nm}$ was used to determine the concentration. The absorption ratio was calculated to be $1.8-2$ for all samples.

\section{PCR Gradient}

To determine the optimum temperature for binding primers, the p21 and GAPDH reference genes were multiplied by the primers and then observed on $2 \%$ agarose gel (fig. 2). The optimum temperature was calculated to be $54^{\circ} \mathrm{C}$ for the p21 gene (fig. 3) and $58^{\circ} \mathrm{C}$ for the GAPDH gene (fig. 4). 
Gastro

Intestinal

Tumors

Fig. 1. Percentage of men and women in the study groups.

Fig. 2. Results of RNA extraction from patient material on $2 \%$ agarose gel.

Fig. 3. Determining the optimum temperature for $p 21$ (146 bp).

Fig. 4. Temperature gradient of the GAPDH gene.

\begin{tabular}{l|l}
\hline Gastrointest Tumors 2015;2:144-164 \\
\hline DOI: 10.1159/000441901 & $\begin{array}{l}\text { @ 2015 S. Karger AG, Basel } \\
\text { www.karger.com/gat }\end{array}$ \\
\hline
\end{tabular}

Salari Fanoodi et al.: p21 Gene Expression Evaluation in Esophageal Cancer Patients
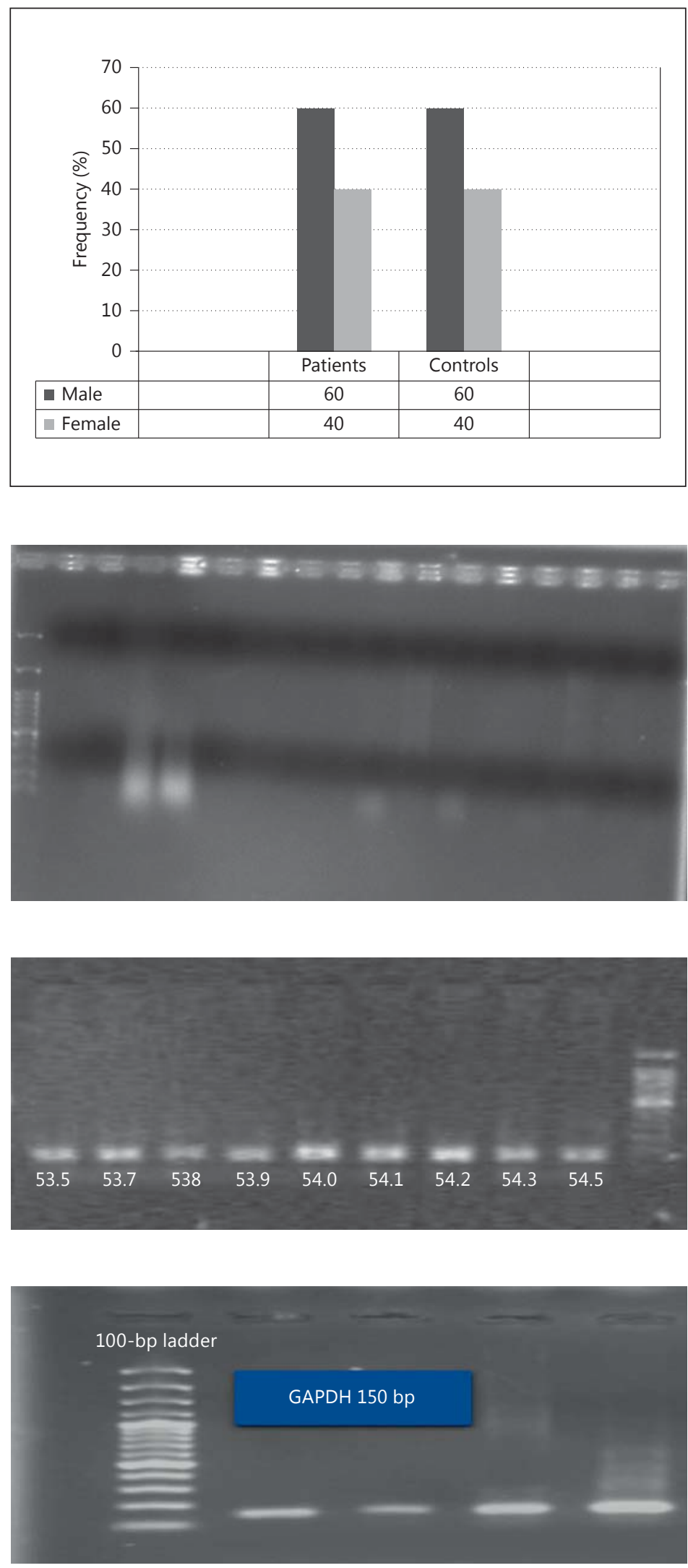


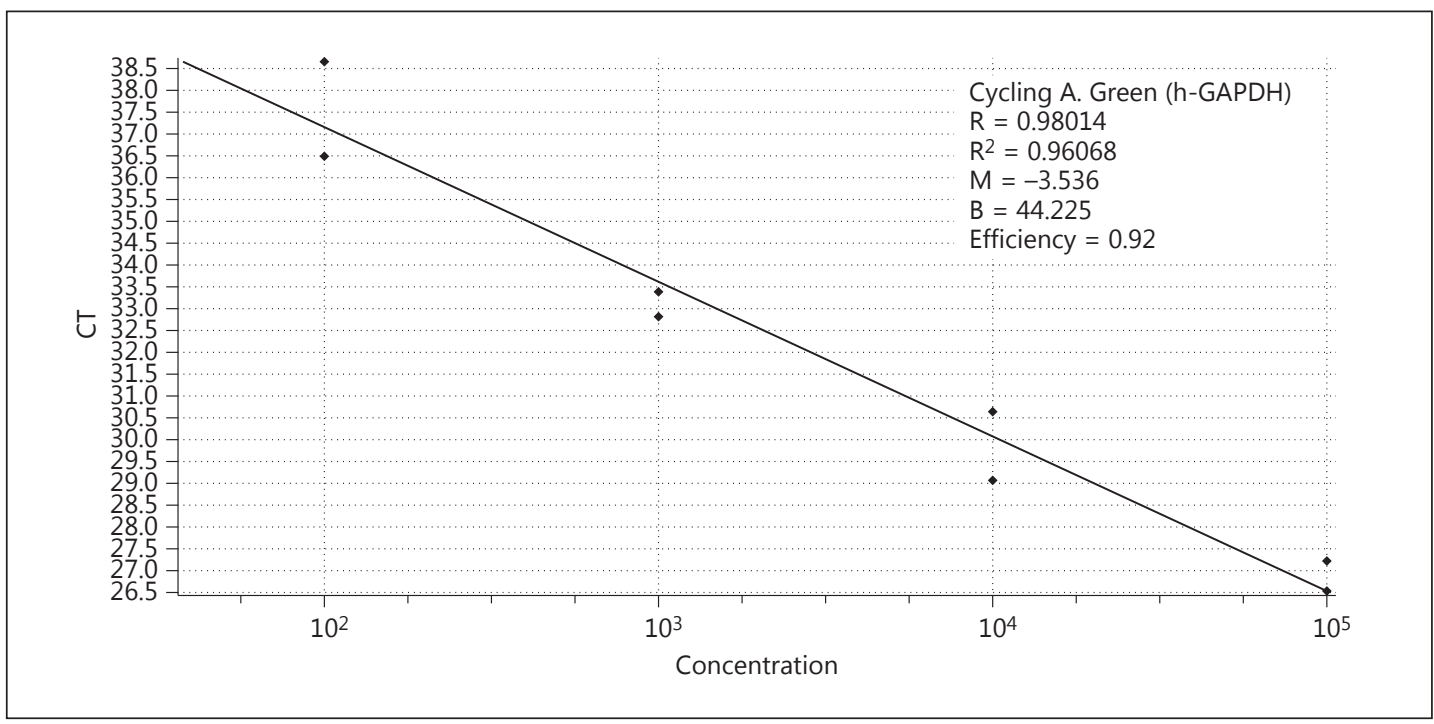

Fig. 5. Standard curve of the GAPDH gene.

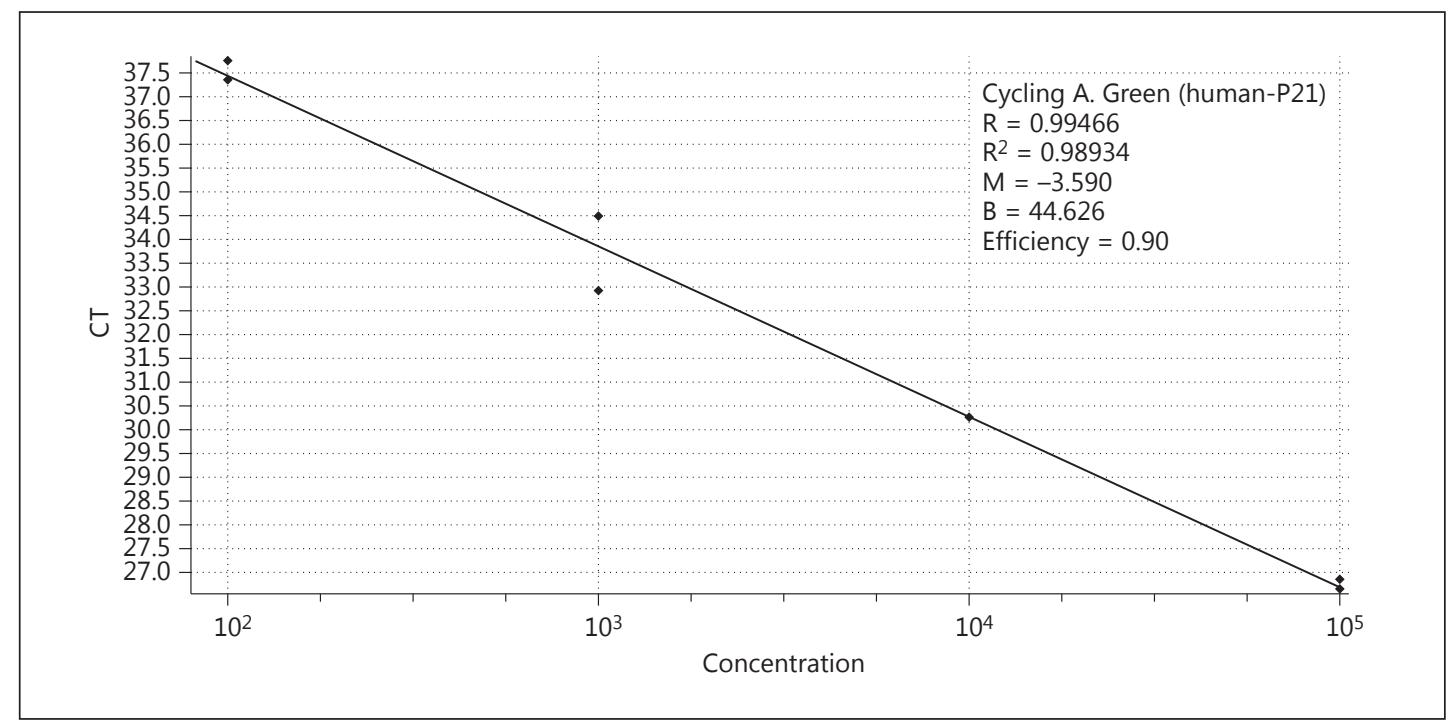

Fig. 6. Standard curve of the $p 21$ gene.

\section{Real-Time PCR}

Optimal cDNA was observed for real-time PCR reaction. After the reaction, the Ct values of samples were determined for all prepared dilutions by GAPDH primers from the reproduction charts, and then the curves were drawn (based on Ct on the y-axis and log of copies on the $\mathrm{x}$-axis). When the standard curve was drawn, the reaction output was calculated at 0.92 for the GAPDH gene, and the $\mathrm{R}^{2}$ degree at 0.96 (fig. 5).

\section{Standard Curve of the p21 Gene}

The Ct values of samples were determined for all prepared dilutions by GAPDH primers from the reproduction charts, and the curves were drawn (based on $\mathrm{Ct}$ on the y-axis and log 


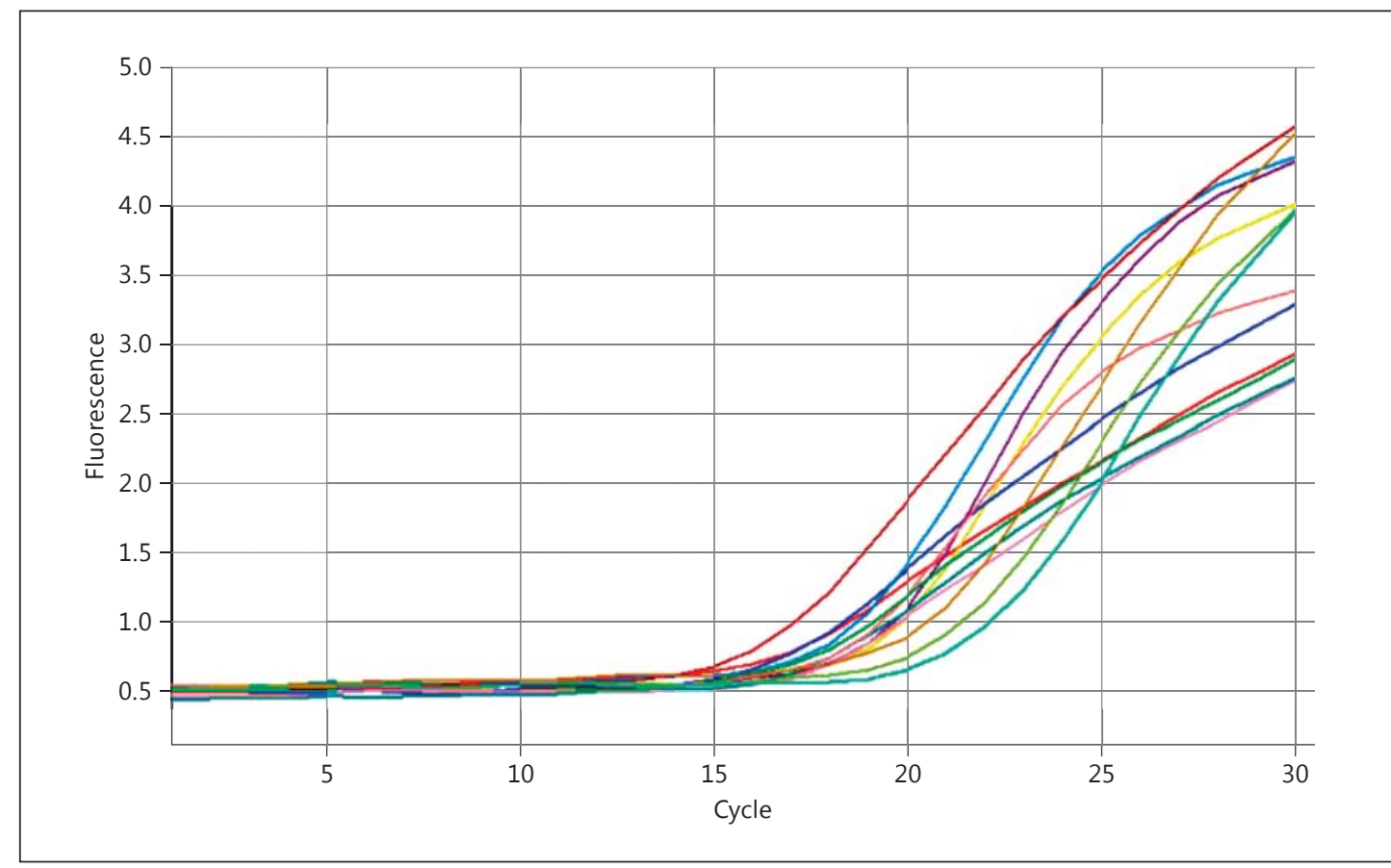

Fig. 7. GAPDH gene amplification curve.

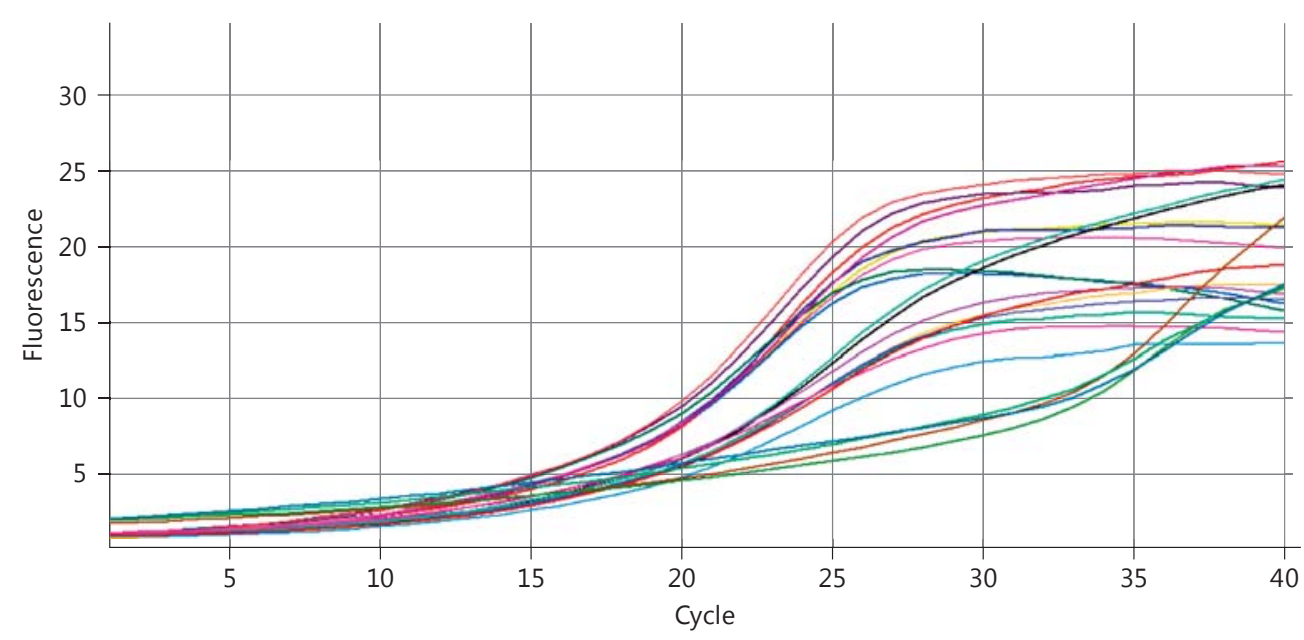

Fig. 8. $p 21$ gene amplification curve.

of copies on the x-axis). The standard curve was drawn (fig. 6), and the reaction output was calculated at 0.90 for the $\mathrm{p} 21$ gene, and the $\mathrm{R}^{2}$ degree at 0.96 .

Figure 7 shows the progress curves of the GAPDH gene amplification reaction during each cycle. Here, the number of cycles is indicated on the horizontal axis and the intensity of the fluorescent light emitted from the device on the vertical axis. Figure 8 shows the progress curves of the p21 gene amplification reaction during each cycle. Here, the number of cycles is 


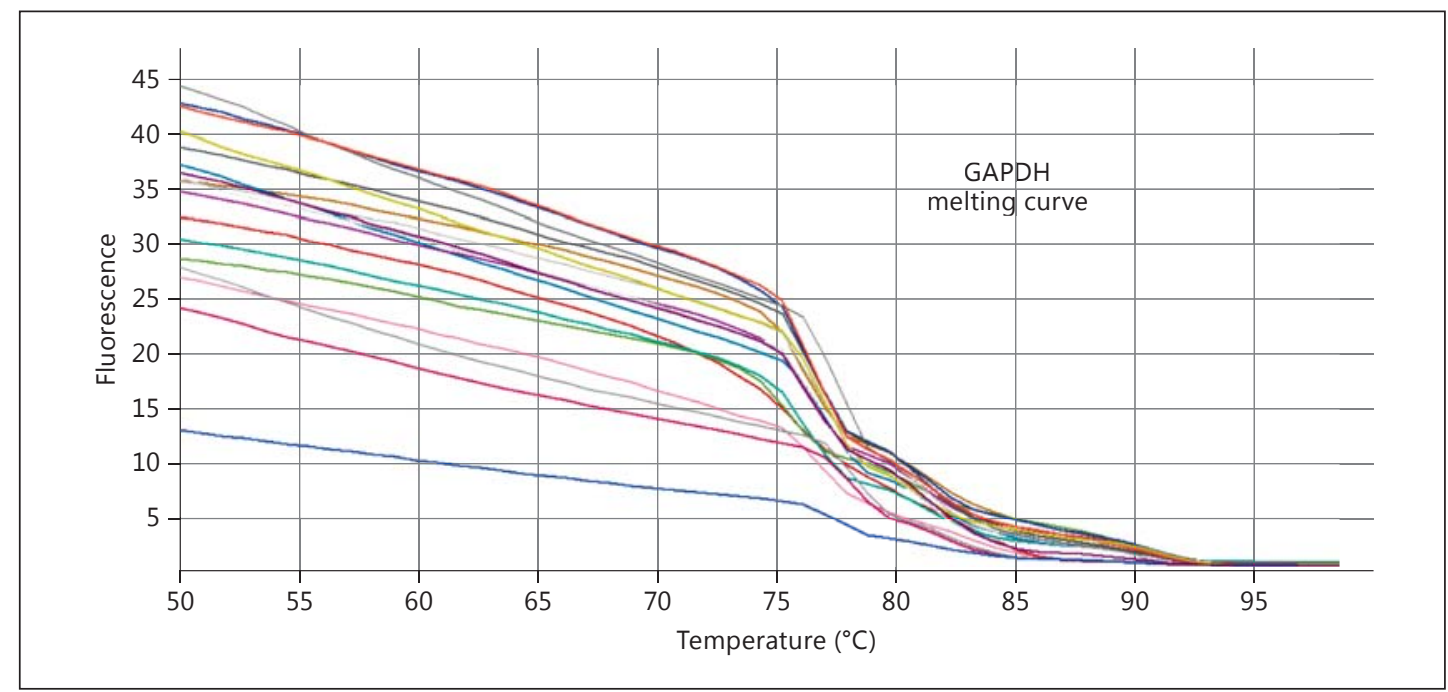

Fig. 9. Fluorescence changes the curve according to GAPDH gene temperature.

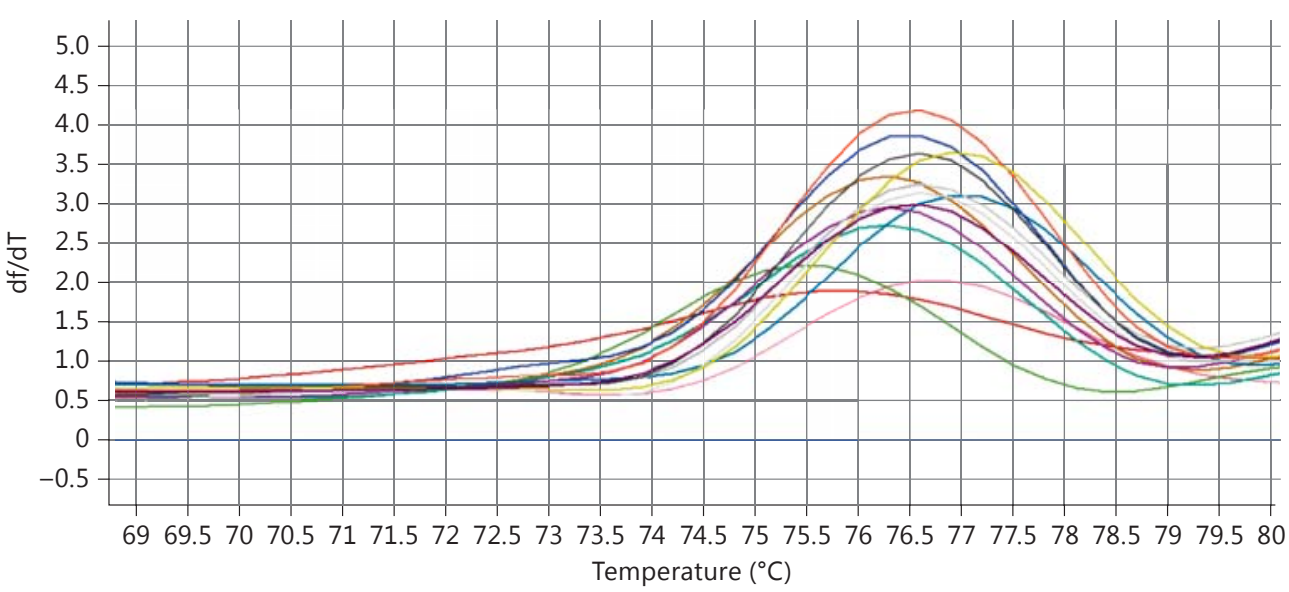

Fig. 10. Melting curve of the GAPDH gene.

indicated on the horizontal axis and the intensity of the fluorescent light emitted from the device on the vertical axis.

\section{Melting Curve Analysis}

The main advantage of real-time PCR is the melting curve, with which a variety of products in the PCR process can be determined. To draw the curve, the device changes the temperature of samples at specified intervals to a certain degree. The speed of changes is shown on the y-axis, and the device's temperature is shown on the $\mathrm{x}$-axis.

Melting Changes the Curve Depending on the Temperature of the GAPDH Gene

To plot the curve, the increase in sample temperature and the light emitted from the samples are measured. In figure 9, a sudden drop in the intensity of fluorescent light can be 


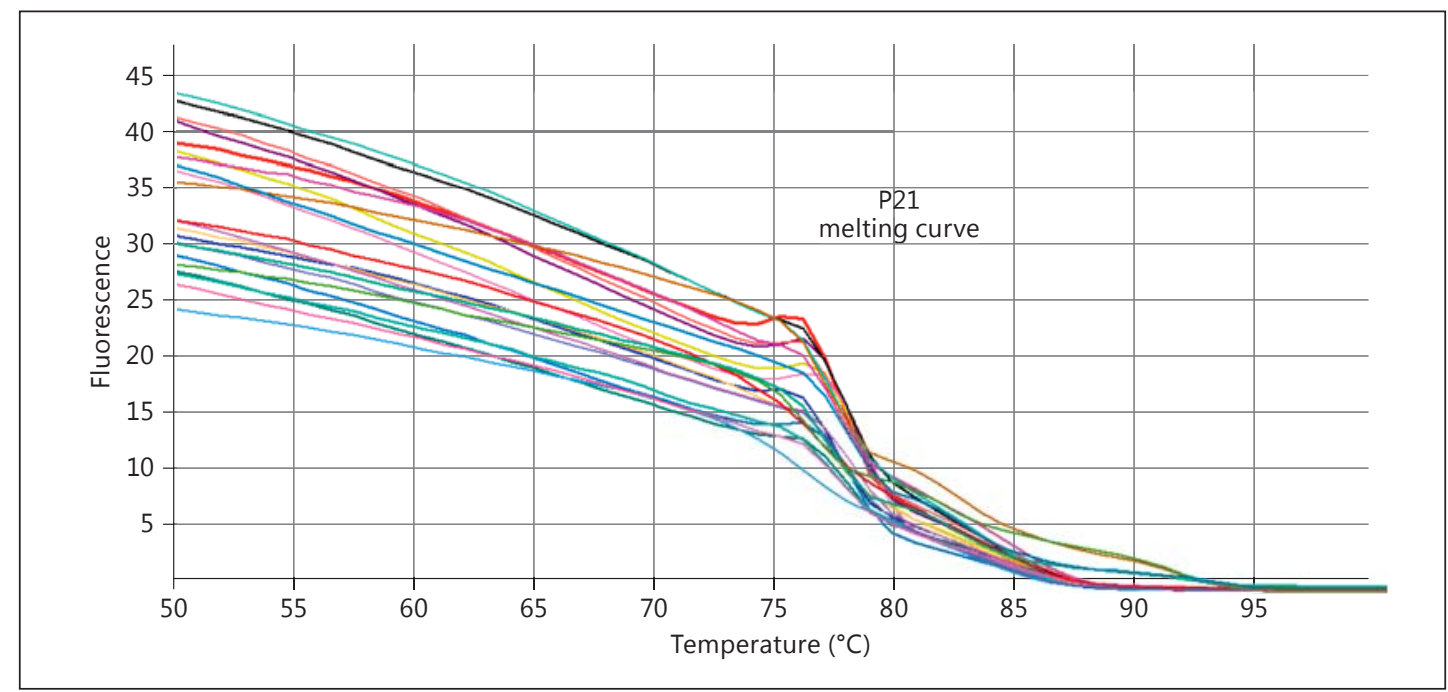

Fig. 11. Fluorescence changes the curve according to $p 21$ gene temperature.

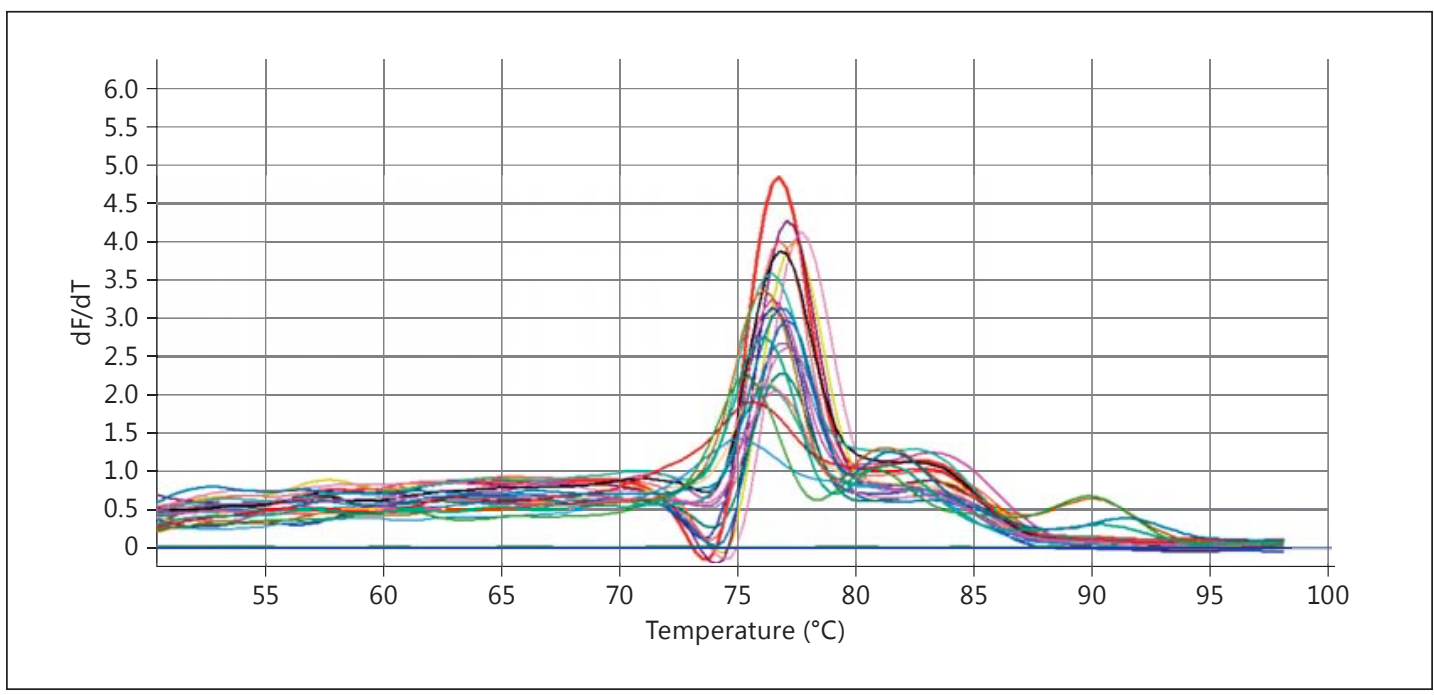

Fig. 12. Melting curve of the $p 21$ gene.

seen at a temperature of $75^{\circ} \mathrm{C}$ for the GAPDH gene. In figure 10 , each peak represents a product. The melting peak also includes a peak at $76.5^{\circ} \mathrm{C}$ and the temperature of the GAPDH gene product.

The sample temperatures increase gradually, and the light emitted from the samples is measured. With the rise in temperature, DNA becomes double stranded, and colored molecules are separated from this product. The intensity of the fluorescent light decreases with temperature increase until the temperature reaches $75^{\circ} \mathrm{C}$, which is the melting temperature of the PCR reaction product. The intensity of the fluorescent light is reduced (fig. 11), and a melting curve is created (fig. 12). 


\section{Tumors}

Fig. 13. Results of confirming synthesis.

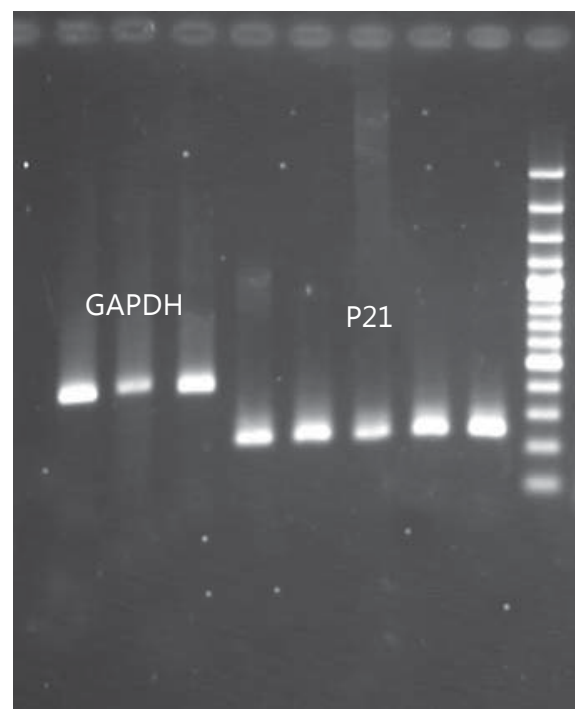

Fig. 14. Comparison of mean $\Delta \mathrm{CT}$ in healthy and patient populations.

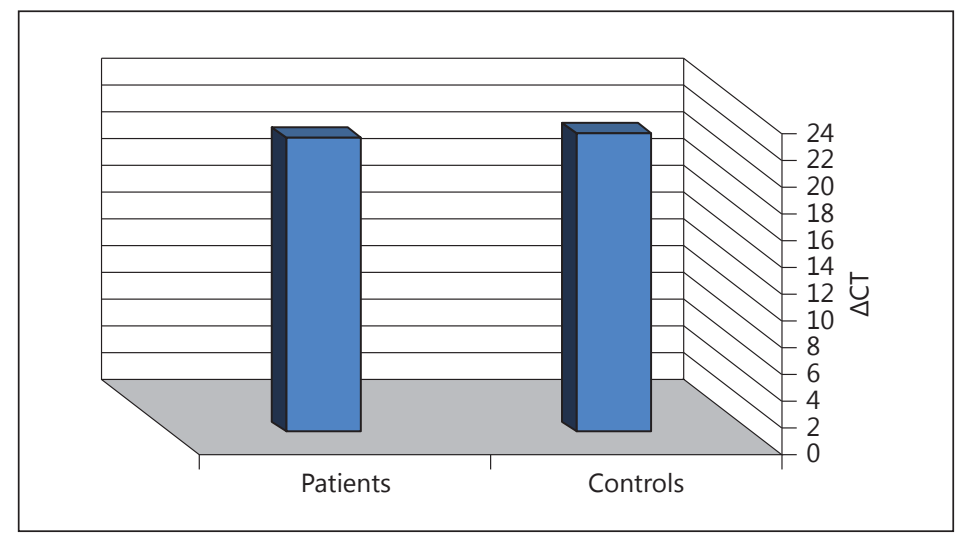

\section{Confirmation of cDNA Synthesis}

To ensure proper synthesis, GAPDH was performed for all samples by the p 21 gene. In both cases, the existence of a band with the desired size and the absence of nonspecific bands indicated the success of the cDNA synthesis (fig. 13).

After $\Delta \mathrm{Ct}$ was calculated for the $p 21$ and GAPDH genes, the data were analyzed using SPSS software and the t test method. No significant difference was observed in $\mathrm{p} 21$ gene expression between patients and controls ( $p>0.05$ ) (fig. 14). Moreover, no significant difference was observed in p21 gene expression between males and females $(p>0.05)$. The analysis of data showed a $\mathrm{p}$ value $>0.05$, so no statistically significant difference exists in the amount of $\mathrm{p} 21$ gene expressed between healthy and sick people in the study groups. In addition to the statistical analysis performed by the t test, ANOVA was used to confirm the results of the test. The results showed no statistically significant difference at the significance level of $p>0.05$.

\section{Discussion}

Protein p21 exists in low amounts in most cells being reproduced. As protein p53 is activated by DNA fractures or intermediate replicators, it is connected to motifs in promoter CDKN1A (the gene coding the p21 protein) and increases the transcription of the CDKN1A 
gene sharply. However, the transcription of the CDKN1A gene is impaired in cancer cells produced during p53 mutations and thus fails to limit the progression of the cell cycle in response to DNA damage and the incomplete cloned chromosome. The intracellular levels of this protein increase in cancerous tissue due to p53 gene mutations and the increased halflife of the mutant form of the protein, but the protein cannot express the $\mathrm{p} 21$ gene due to lack of normal function. Regarding the activation pathways of $p 21$ (dependent on p53 and independent of p53), increased expression of $p 53$, cyclin D, Myc, and Ras causes a lack of or reduction in $p 21$ expression. The biological and network adjustment activity of the $p 21$ complex makes predictions about its function to make cancer treatment possible. No relationship between the expression of $p 21 \mathrm{WAF} 1$ and clinical pathological parameters was found regarding sex and age [21].

The cell cycle is crucial for cell survival. Various factors and proteins coordinate, regulate, and control this cycle at many set points in positive or negative ways. In fact, various genes exist in the cells which encode the required proteins for cell cycle control. Extensive studies show a sophisticated correlation between cell cycle time and cancer. Researchers have identified several inhibitor proteins and their function during the cell cycle. Inhibitor proteins ensure the correct DNA replication and cell cycle in normal conditions; obviously, mutations in the genes replicating them or regulating their expression or activity have a central role in the development of cancer. It is generally accepted that multistage genetic and epigenetic changes cause normal cells to mutate into malignant cells. This causes the cells to act independently of the proliferative regulation and cell death cycle and also stimulates the proliferative, infiltrative, and metastatic capacity of cells [22].

One of the main reasons for changes in cells in mammals is the loss of the appropriate cell cycle control. The p21 gene, a CDK inhibitor (also known as p21WAF1/Cip1), stimulates the cell cycle arrest in response to many stimuli [23]. The p21 gene, an important regulator of the cell cycle, binds to PCNA and acts as a mediator in the function of the $p 53$ gene, suppressing growth and promoting cell death [24]. Since all tumors, benign or malignant, are formed because of uncontrolled cell growth, a disturbance in tumor cell growth regulators is logically one of the main reasons for tumors being created.

Molecules inhibiting growth are particularly important, because proteins prevent the amplification of cells containing a defective genome by inhibiting the cycle [25]. Two groups of genes are involved in carcinogenesis, namely oncogenes such as K-Ras and suppressor genes such as $p 53$, APC, and DCC/DPC4, and all MMR genes; mutation occurs earlier in the $\mathrm{APC}$ and MMR genes in the process of developing a tumor, and $p 53$ mutation is one of the final events in this pathway [26]. Such inhibitors include $p 53$ and its associates, like the p21 gene. Studies on molecular mechanisms during the development process of cancers and technology progression are one of the reasons for valuing molecular markers [27]. Methods for assessing efficacy are available to researchers today, enabling them to quickly assess and confirm new genes, mRNA copies, and proteins. Differences in the expression of these molecules in healthy and malignant tissue allow the identification of genes and changes in pathways in human cancers. CDKs play an important role in the cell cycle. They are activated by positive regulators and inactivated by inhibitor factors [28]. Among these inhibitors, the p21 protein belongs to the Cip/Kip family and inhibits it by connecting to cyclin-CDK. The Walf/Cip1 gene on chromosome 6 encodes the p21 protein and is expressed in two pathways: dependent on and independent of $p 53$. Its activity results in stopping the cell cycle, facilitating the repair of damaged DNA, a growth stop in the last stages of differentiation, being involved in the aging process of cells, and preventing apoptosis [29].

In this study, $p 21$ was assessed in 15 healthy subjects and 15 esophageal cancer patients, and the results indicated no expression of this gene in the samples. Studies on similar samples showed an increased expression of $p 53$ and cyclin D simultaneously in squamous esophageal 
tissues. The association between these two genes is reviewed below. Since disorders in the $p 53$ gene and protein are the most common problems in human tumors [30] and $p 21$ plays an important role in their activity pathway, the $p 53$ gene can be cited as a key factor. Its mutation leads to the survival of the damaged cell and uncontrolled cell growth by allele deletion, gene mutation, or protein destruction [31]. Although mutation in the $p 53$ gene is accompanied by a concentration of $p 53$ protein in tumor cells, it is not followed by p21 gene expression due to the nature of the protein [29]. p21 protein, unlike $p 53$, is also considered as an antiapoptotic factor [28]. Expression of this protein in normal and cancerous cells occurs in pathways dependent on and independent of $p 53$. There is no direct association between $p 53$ and $p 21$ in noncancerous tissues. In normal conditions, $p 21$ is expressed in a pathway dependent on $p 53$ in a cell, being amplified when exposed to mutagens or during the process of cell differentiation, and it inhibits DNA amplification by either inhibiting CDKs, interacting with core antigens related to amplification, or playing an important role in the final cell differentiation. Mutation in the $p 53$ gene and abnormal function of its protein increase intracellular $p 53$ protein, but cannot express the p21 protein [29].

Regarding the direct association between $p 53$ and cell cycle regulation, it seems that CDKN1A encodes $p 21$ and regulates its transmission from different stages of the cell cycle. In most cells being reproduced, the $\mathrm{p} 21$ protein exists in low amounts. As $p 53$ is activated by the breakage of DNA or matching intermediates, it connects to the motif linkage in the CDKN1A promoter and increases transcription of the CDKN1A gene significantly. In cancerous cells generated during mutations of $p 53$, however, the transcription of the CDKN1A gene is distorted and thus fails to limit the cell cycle progression in response to damage to DNA and incomplete replicated chromosomes. In the cell cycle, the $p 53$ protein affects $p 21$ following stress and DNA damage, and it inhibits the cell cycle and suppresses tumor function.

In most cases, $p 53$ protein tissue is found in its mutated form in tumors. Other factors may inhibit and prevent the expression of $p 21$ in pathways other than $p 53$ [30]. However, recent data from both artificial and live tissue suggest that the p21 gene can be regulated independent of $p 53$ [32]. In cancerous tissues, $p 53$ is mutated, the half-life of the mutated protein is increased, and the internal amounts of this protein increases, but it cannot express the 21 protein due to the lack of normal function. Regarding the path independent of $p 53$, studies have shown that the relationship between these two proteins is different depending on the cell type, tumor tissue, and different phases of differentiation [29]. Thus, it seems essential to assess mechanisms of inhibition and activation while studying $p 21$ to better understand tumorigenesis mechanisms. This may explain the variance in reports indicating the repetitive changes of $p 53$ in ESCC, while the correlation between the mutation of $p 53$ and the p21 protein in ESCC is controversial and needs further clarification [33, 34].

p21 generally inhibits gene amplification, but it can activate gene amplification under certain conditions. The role of $p 21$ in improving inhibition of the cell cycle dependent on $p 53$ and due to DNA damage is well defined [35]. The basis for $p 21$ activities in the nucleus and cytoplasm in certain situations can be studied as follows: $p 21$ improves the kinase activity of CDK4/cyclin D or CDK6/cyclin D complex, and so controls improvement through $\mathrm{G}_{1} . p 21$ prevents CDK2-cyclin E, the phosphorylation dependent on CDK2 for retinoblastoma, and E2F1, thereby inhibiting gene amplification dependent on E2F1 and progression through the $S$ phase. $p 21$ prevents kinase activity of CDK2-cyclin A and CDK1-cyclin A, which are retrospectively required for progression through the $S$ and $G_{2}$ phases. In addition, $p 21$ prevents kinase activity of the CDK1-cyclin B1 and progression through $\mathrm{G}_{2}$ and $\mathrm{G}_{2} / \mathrm{M}$. $p 21$ also prevents the amplification of PCNA through the terminal carboxyl and thereby prevents the synthesis of DNA and modulates routes of DNA repair.

p21 can prevent the amplificatory activity of amplification factors E2F1, STAT, and Myc through a direct connection. Some antiapoptotic effects of $p 21$ are thus explained which can 
help its gene alteration activities. Phosphorylation of $p 21$ in Thr145 prevents the amplification of nuclear $p 21$ by downstream AKT1 activated by ERBB2 (a member of the epidermal growth factor receptor tyrosine kinase) or IKK $\beta$ [36-38]. Cytoplasmic $p 21$ prevents antiapoptosis by preventing proteins involved in cell death. It is not clear whether phosphorylation of $p 21$ by AKT1 or p21 alone acts in the cytoplasm or is required for cytoplasmic activity.

Genes inhibiting the mutated oncogene $p 53$ and TGF $\beta$ paths of tumors, both of which inhibit the growth of most cancer cells, include tumor-inhibiting genes. Inactivation of one of the tumor-inhibiting genes causes unbridled tumor cell amplification. Conversely, RAS and PI3K pathways, which are involved in increasing cell growth, include many proto-oncogenes that are often mutated. Oncogenes permanently activate growth stimulators. There are also pathways that include both cancer genes; in such pathways, the mutations that inactivate the tumor inhibitors and the mutations that activate the proto-oncogenes have paradoxical effects on the function of the pathway.

The cancer gene pathways play an important role in the discovery of cancer genes. Reports on overexpression of cyclin D in esophageal squamous cell cancer indicate that a high cyclin D level can be related to the upstream cancer gene pathways. The RAS pathway increases CCND1 expression, while WNT/APC inhibits CCND1 expression by inhibiting $\beta$ catenin. In addition, CCND1 is the direct target of activating the transcription dependent on c-Myc. The first known function of Myc is its ability to trigger cell division. Myc causes the expression of cyclin D and reduces the expression of $p 21$. Myc is a strong proto-oncogene, and its expression increases in many cancers [39].

While the rise of unregulated $p 21$ in cancers is often related to the reduction of the proliferative activity of $p 21$ (including $p 53$ ), upregulation or strengthening mutations in gene activity (that suppresses CDKNIA amplification) can contribute to the spread of cancer. For example, it is possible that suppressing CDKNIA amplification (the gene encoding $p 21$ protein) affects the spread of cancer by Myc in cases where Myc expression is increased. This may be important in ER $\alpha$-positive breast cancers; the upregulation of estrogen-dependent Myc and downregulation of $p 21$ increase cell amplification, and failure in connection with Myc-p21 in resistance to antiestrogen treatment may also play a role [40].

Significantly, Myc proliferates AP4, an amplification factor that is increased in colony sample cells, colon, and rectum cancers, and can inhibit CDKNIA amplification [41]. AP4 significantly prevents inhibition of the cell cycle through $p 53$, sensitizes cells to cell death induced by DNA damage, and can suppress TGF $\beta$-dependent CDKNIA amplification [41]. The loss of inhibiting TGF $\beta$ growth activity is a signal of many cancers [42], so it seems that AP4 and other factors that prevent $p 21$ expression and obstruct growth inhibition by TGF $\beta$, such as miR-106b-25, a recently identified microRNA group [43], can help spread these cancers.

CDKNIA activation in response to a range of stimuli, including damage to DNA, depends on $p 53$ and its co-member p73. CDKNIA amplification induced by H-RAS and BRCA1 mediated by mechanisms dependent on $p 53$ and independent of $p 53$ have also been shown. The activation of CDKNIA amplification is performed by growth factor, nuclear receptors, chemicals including anticancer agents (such as HDAC inhibitors), and drugs with antiproliferative activity (such as statins). Myc suppresses CDKNIA amplification by binding to Sp1 and preventing Sp1 [44], and this could be reduced by connecting the nuclear receptor hepatocyte nuclear factor of ligand $4 \alpha_{1}$ (HNF4 $\alpha 1$ ) to Sp1 [45]. In response to damaged DNA, Myc is used to promote CDKNIA by MIZ-1 and form a triple complex of DNMT3a methyl transferase DNA that suppresses CDKNIA expression [46]. Moreover, AP4, a main helical ring/helical protein and the amplification target of Myc, suppresses CDKNIA through connectivity to four E-box motifs independent of MIZ-1, Sp1, or Sp3 [41]. The proliferative circuit of CDKNIA includes proliferative factors which prevent cell growth, differentiation, or senescence, and up- or downregulates CDKNIA expression under different circumstances. Some of these factors act 
in the proliferative networks, such as: adenomatous polyposis coli; C/EBP $\alpha$ (CCAAT/enhancer binding protein- $\alpha$ ); CREBBP (CREB-binding protein); FGF2 (fibroblast growth factor 2); GAX or MOX2; HOXA10 (homeobox A10); IFNү; IL-6; KLF4 (Krüppel-like factor 4); nerve growth factor; NRG1 (neuregulin); okadaic acid; phorbol-12-myristate 13-acetate; progesterone receptor; signal transducer and activator of transcription; TGF $\beta$, and thrombopoietin [23].

Most studies on the role of $p 21$ in cancer consider rat studies combined with factor analyses and biochemical methods in cell culture. The pioneering work that led to the early detection of $p 21$ described the tumor-suppressing activity of $p 53$ as a potential mediator [47]. Subsequent work showed that CDKNIA deletion in mice terminates a growth inhibition dependent on $p 53$ and induced by DNA damage $[48,49]$. Thus, $p 21$ cannot explain the tumorsuppressing activities of $p 53$; however, it is the main determinant of tumor protection by $p 53$ [50] as CDKNIA deletion greatly accelerates tumor generation in mice in a state of mutated $p 53$, which is unable to induce cell death, but maintains partial growth-inhibitory activity [51]. The first genetic evidence to confirm the tumor-suppressing activity of p21 originated from the discovery that CDKNIA developed spontaneous tumors [52]. Secondly, these tumors (mean age of 16 months), compared with those resulting from a deficiency in other tumor suppressor genes in mice, such as Trp53 [53], p16 [54], or Arf [55], suggest that a drop in CDKNIA itself is not enough for the deterioration of malignancy. Although many human cancers such as those of the colon and rectum, those in the area between the head and the chest, head and neck, and small lung cancers are related to the reduced form of $p 21$, rare mutations resulting in the reduction of CDKNIA activity in human cancer $[56,57]$ indicate that p21 may not be a classic tumor suppressor. Instead, $p 21$ has synergy with tumor suppressors and fights change in genes to protect against cancer. CDKNIA shortage with the participation of $H$-ras and $M y c$, the emergence of BCR-ABL1 [58], or with LNK4 deletion helps the progression of cell conversion and reproduction in culture. Together, these data are consistent with the theory of multistage tumor and the role of $p 21$ in this process.

Proliferative regulation of $p 21$ has been largely studied [59]. In cells without conversion or perishable duplication of chromosome, Ras gene change activates CDKNIA proliferation through two independent mechanisms, both related to and independent of $p 53$. Independent replication of $p 53$ needs the amplification factor of E2F1 for CDKNIA with activated Ras. E2F1 and E2F3 binding to the cis-active elements 119 and 16+ of CDKNIA strongly activate the proliferation of CDKNIA [59, 60]. Raf, a downstream effector of Ras, also exchanges CDKNIA independently of $p 53$ [61]. Raf and Ras induce gene change and aging related to $p 21$, and other genetic mutations that are important obstacles for the creation of tumor-like cell death are necessary to discard gene change-induced cell aging and death [62].

The important role of $p 21$ in increasing $\mathrm{H}$-ras-induced aging is confirmed by the finding that eliminating CDKNIA helps H-ras to activate tumor progression [63-65]. It is likely that the expression of genes involved in programming, such as SOX2 and OCT4, and the decreased expression of $p 53$ and downstream objectives such as $p 21$ and miR-145 are involved in cancer [25]. AMAPK acts in identifying cell stress. Energy shortage causes cell stress. By identifying the cell stress message and immigration to core, it is attached to protein $p 53$, which turns off the tumor. Then, one phosphate connects to the histone near the p21 gene and causes the illumination of this gene. $p 21$ activity delays the cell cycle or causes it to stop until the energy level of the cell has returned to normal.

It seems that viral factors can also abolish gene expression. Many viral proteins affect the stability or regulation of postproliferative $p 21$ using the influence of cell proliferation. For example, the E6 protein of the human papillomavirus (HPV) can downregulate $p 21$ independently of $p 53[66,67]$. Although E6 is necessary for the genetic change of HPV and has antiapoptotic activity, it can downregulate $p 21$ to enhance cell death [68] under some 
circumstances, such as damaged DNA [66]. Virus type 2, associated with a tumor, preferably downregulates p21 protein in cells infected with HPV, with continuous increased activity of CDK2-cyclin E, but prevents the advance into the $\mathrm{S}$ phase; thus, it helps repeat tumor-associated virus type 2 [69]. The core protein of the hepatitis $C$ virus prevents $p 21$ postproliferatively, reduces inhibition of CDK2, and helps cause tumors by hepatitis C [70]. Finally, cyclin $\mathrm{K}$ encoded by herpesvirus 8 increases the phosphorylation of $p 21$ in Ser130 by CDK6 without affecting its stability or cytoplasmic-nuclear position [71]. Interestingly, although the phosphorylation of $p 21$ in Ser130 by CDK6 induces spread by E3 SCF ${ }^{\text {SKP2 }}$ (SKP1-CUL1-SKP2) and breakdown, the phosphorylation of $p 21$ by CDK6-cyclin K prevents the relationship of $p 21$ with CDK2, thereby reducing the inhibition of phase $\mathrm{G}_{1}$ due to $p 21$ [71]. The mechanism by which viral proteins affect the stability or activity of $p 21$ is unknown. These findings suggest that $p 21$ appearance is a common mechanism that regulates these viruses to cell cycle progression and cell death. RNA viruses as well as DNA viruses separately play important roles in the process of carcinogenesis by activating oncogenes and inactivating tumor suppressor genes, respectively.

An understanding of the role of $p 21$ in suppressing tumors has been achieved from the study by Shen et al. [72], which shows a prominent tumor suppressor role for $p 21$ regarding genomic instability. CDKNIA shortage along with a drop in ATM protein helps the development of chromosomal changes, which increases tumor progression [72]. Although the expansive malignancies of $\operatorname{Tr} 553^{\mathrm{R} 172 \mathrm{P}+/+}$ keep stable genomes in mice, lymphoma and malignant tumors of connective tissue originate from $\operatorname{Trp} 53^{\mathrm{R} 172 \mathrm{P}+/+}$; rat CDKNIA has an early invasion and shows particular chromosomal aberrations and changes in chromosome number [51]. The finding that downregulation of $p 21$ is inversely correlated with microparasite instability in colon cancer, regardless of $p 53$, confirms that the loss of protection against genomic instability by $p 21$ helps malignant human conditions.

Some research suggests that the absence of $p 21$ followed by an increase in the number of stem cells (such as keratinocytes) is strongly correlated with increased cancer ability [7375]. Nevertheless, $p 21$ has recently been shown to determine the maintenance of the selfreplicating capacity of leukemic cells in rats with gene change PML PAR by protecting against deterioration caused by stressful conditions [76]. The results demonstrate that $p 21$ is important for survival in at least a subset of malignancies. The results also show that this $p 21$ activity can vary depending on a specific genetic change. Jaiswal et al. [77] investigated gene polymorphism of $p 21$ at codon 31 and dinucleotide gene polymorphism of $p 73$ regarding susceptibility to bladder cancer in northern India. The results showed that $p 73$ gene polymorphisms are associated with susceptibility to bladder cancer, but no relationship exists between $\mathrm{p} 21$ gene polymorphism at codon 31 and susceptibility to bladder cancer. This result is consistent with the results obtained in the current study. Taghavi et al. [19] investigated p21 gene polymorphism and its relationship with smoking in ESCC in northeastern Iran. Their findings showed that none of the $p 21$ genotypes were significantly associated with increased risk of ESCC, and polymorphisms of the p21 gene, alone or in combination, are not biomarkers of a genetic predisposition to ESCC. However, the presence of this polymorphism in combination with smoking was in contrast to the incidence of ESCC cancer in northeastern Iran [18]. This finding is consistent with the results obtained in the current study.

Villwock et al. [22] considered the prevalence of $p 21$ immunohistochemistry in the epithelial tumor of the esophagus. Their results indicated that among 42 patients, 83.3\% were male and older than 40 years. Surgical treatment was proposed to $56.2 \%$ of them: surgery of the whole stomach, or surgery of the stomach and transitional esophagus. Other patients underwent minor surgery or did not undergo any surgical treatment. Only 5 patients underwent chemotherapy and radiation, in combination and alone. Advanced diseases (stages 3 and 5) were detected in $78.6 \%$ of patients. According to the evaluation systems of 
active immunity, only 9 patients were positive for $p 21$. Ultimately, the researchers found that accumulation of $p 21$ did not play a key role in glandular epithelial esophageal cancers in the patient population [22]. This result is consistent with the results obtained in the current study.

Liu et al. [75] investigated the relationship between the state and prognosis of $p 21^{\text {WAF1 }}$ in esophageal squamous cell cancer stage 3 . The results showed that the overall survival rate for the $p 21^{W A F 1}$-positive group was significantly higher than that of the $p 21^{W A F 1}$-negative group. No significant correlation was observed between $p 21^{W A F 1}$ and the clinical pathology parameters according to sex, age, tumor location, tumor grade, pathological stage, and number of lymph node invasions. They concluded that $p 21^{W A F 1}$ plays a complex role in tumor genesis and development of ESCC. $p 21^{W A F 1}$ can be used as a prognosis predictor for patients with ESCC stage 3. This result is consistent with the results obtained in the current study.

Ishida et al. [76] examined the existence of $p 53$ and $p 21$ and the clinical response to temperature shock treatment by radiochemotherapy in patients with ESCC. Multivariate analysis revealed that the existence of $p 21$ is an independent risk factor related to histological effects. None of the 10 patients with negative $p 21$ and positive $p 53$ tumors in their study showed a third-grade response, while the other 55\% combined with the other group did. They concluded that the combination of $p 21$ and $p 53$ in histological findings can predict hyperthermochemoradiotherapy histological function.

Regulation of $p 21$ transcription is widely studied [59]. Positive expression of $p 21$ is associated with disease progression and poor prognosis in prostate [80], ovarian, and breast cancers [81]. Yet, given the frequent increased expression of $p 21$ in human cancers, understanding the mechanism of action of this gene offers considerable insight into the development of human cancers. The inhibition of $p 21$ is in negative correlation with microsatellite instability in colon cancer, regardless of the status of $p 53$; thus, it helps the loss of protection against genomic instability of $p 21$ to human tumors [82]. Studies have demonstrated a reduction in the amount of $p 21$ in verrucous leukoplakia of the mouth, in the incidence of $p 21$ in muco-epidermoid carcinoma of the salivary glands, and in oral ameloblastoma [25]. Studies on colorectal tissue showed the important role of $p 53$ gene mutation in the development of colorectal adenocarcinoma and strengthened the theory of expression of $p 21$ in pathways independent of $p 53$ in colorectal cancer [83]. The amount of expressed p21 is decreased to a greater extent in tumor cells than in nontumorous colons of patients and nonpatients, but it is not related to prognosis.

Differences in the amounts of reported p21 gene mutations in different areas reveal that the incidence of mutation in this gene is strongly influenced by environmental, geographic, and ethnic factors. However, the type of test and the technique used to detect mutation are also very important. The p21 protein is one of the best known proteins related to the cell cycle. Reduction or loss of expression of the p21 protein indicates a poor prognosis in these cancers. As $p 21$ is a prognostic marker and its nonexpression will cause cell amplification, it seems normal that well-differentiated tumors express this marker more and tumors with a higher microscopic stage and lower differentiation express this marker less. This is exactly what the findings of most studies, including the current one, support. As $p 21$ is a prognostic marker and stage has a greater value than grade, the significant relationship between them is rational. Unfortunately, they were not assessed in the current study because of the aforementioned restrictions.

There is an inverse relationship between the prevalence of the expression of the p21 protein, phase of tumor, depth of invasion, and lymph metastasis in colorectal cancer, and the prognosis and survival are desirable in the presence of these proteins [11]. Apparently, the reasons why a lack of gene expression and significant differences were obtained were that the tumor samples assessed were in stages 4 and 5 , gene expression faces changes in the early 
stages of cancer, genes express in the early stages of cell cycle inhibition, and they do not express in the later stages of cancer.

Reduced expression of P21 is associated with an increase in liver and lymph involvement. It is also accompanied by deeper tumor invasion into the muscle layers and a higher stage, which confirms the theory of the current study. The biological activity and network-regulatory activity of P21 complex make predicting its function in treating cancer possible. Different effects of P21 on gene regulation and its role in genomic stability, cell death, aging, and DNA repair may not only help cancer development, but also largely affect the benefit of agents damaging DNA or other drugs that can induce P21. Different anti-cancer agents such as HDAC inhibitors act through their ability to enhance the induction of P21, at least in part [81]. Other factors such as statins (commonly used to decrease cholesterol levels) show a profound antiproliferative capacity by inducing P21 and are being investigated for their antitumorgenesis activity [82]. The only challenges are in the selective inhibition of the genechanging activity of P21 and tumor suppression activities. Therefore, the development of agents that inhibit the ability of P21 to integrate CDK4-D-cyclin and CDK6-D-cyclin complexes and its ability to suppress CDK1 or CDK2 can be an interesting line of study. Likewise, instead of P21 markup, selective marking of upstream and downstream factors of P21 that affect the specific aspects of its activity is beneficial. Drugs that can block the anti-apoptotic activities of P21 are probably particularly effective when combined with other drugs that can induce P21, such as agents that damage DNA. Remarkable progress has been newly achieved. Structural and biochemical studies of different ligase complexes directly involved in the analysis of P21 protein under different conditions will undoubtedly help the development of selective inhibitors for these ligases and provide guidance on how to develop a new generation of anticancer agents. In addition, DNA-damaging agents may selectively inhibit the activity of AKT1, may not only prohibit tumors from AKT1 activities or possibly unstable P21, and may lead to an increase in their apoptotic effects. It is likely to be confirmed by research that the DNAdamaging agent aminoflavin can induce cell death of MCF7 breast cancer cells only at concentrations that reduce the activity of AKT1 and unstable P21. Alternative treatment methods may be replaced using the ability of P21 to induce senescence in tumors. Recent work suggests that tumor regression can be achieved through the reactivation of aging, for example by restoring P53 activity or disabling Myc in tumors with P53 [83]. Despite the inactivation of Myc from P21 with up-regulation in a subset of tumors, the results demonstrate that the activation of aging is not only possible, but is also a promising approach to regressing tumors in living tissue. Even in tumors with high amounts of P21, tumor regression through the reactivation of aging is possible. Nevertheless, this possibility requires a greater understanding of the various factors that can destroy P21-induced aging despite high levels of P21. The appearance of P21 in these tumors can potentially be used for treatment by marking ID1 or similar molecules that will lead to the reactivation of the aging process of P21. Finally, the need for scientific progress to identify the exact role of P21 in modulating DNA repair processes under different conditions is strongly sensed and may lead to new strategies of the role of P21in the development and treatment of cancer [23]. Expression of P21 gene by the adenovirus vector was able to reduce cell growth. Cell growth inhibition was associated with the induction of a squamous cell marker. The researchers performed P21 gene therapy using a gene gun technology. Gene delivery, using a gene gun, uses a shock wave to accelerate the entry of micro-particles covered with the plasmid to the target cell or tissue. Since this method is not associated with cell surface receptors, it can introduce genes into a wide range of mammalian cells. The gene gun is simpler and less aggressive than other forms of gene delivery. Significant inhibition of growth was observed in cells that did not express P21 after this method was used. The impact of P21 protein on the treatment varies depending on the expression direction, and many consider its activity with higher sensitivity to chemo- and radiotherapy in the presence of the 
P53 natural protein. Analysis of gene expression may be useful in providing information on the factors affecting prognosis. One of the best functions of using real-time PCR is gene expression assessment using relative quantification; this method is the most accurate way to detect changes in gene expression. In this method, only an increase or decrease in gene expression is important, and the increase or decrease is compared with the standard, the internal control. This method is cost-effective economically and in terms of time [84]. The advantage of real-time PCR is the use of a reference gene, which is continually expressed in all cells under investigation; a detailed assessment can be carried out with this gene despite the changes in RNA quality and efficiency of each reaction. The reference gene should be expressed in all samples at the same level; otherwise, the normal process will result in errors in the results. Test method and identification technique are important. Different immunohistochemical studies analyzed P21 in a variety of tumors. Some studies reported a relationship between P21 status and worse prognosis in breast [14], anal [15], bladder [16], and ovarian cancer [17] and poor prognosis in prostate cancer [77]. They have also observed no significant difference in esophageal cancer (adenocarcinoma). However, no research has been conducted on this gene and these cancers using real-time qPCR. This study investigated the expression of P21 by real-time qPCR for the first time in Iran. It is hoped that this study will be a prelude to designing prospective cohort studies with patient follow-up, investigating survival status, recurrence, response to treatment, and determination of relationships with other genes involved in esophageal cancer.

\section{Conclusions}

The results indicated no significant difference in p21 gene expression between patients and controls ( $p$ > 0.05). Moreover, no significant difference was observed in p21 gene expression between males and females $(\mathrm{p}>0.05)$. It appears that $p 21$ is not a specific tumor marker in Iranian esophageal cancer patients.

\section{Acknowledgements}

We would like to sincerely thank the Center of Agricultural Biotechnology, University of Zabol, for their cooperation in the process of this research.

\section{Statement of Ethics}

The authors declare that there are no ethical issues in this article including plagiarism, informed consent, misconduct, data fabrication and/or falsification, double publication and/or submission, redundancy, etc.

\section{Disclosure Statement}

The authors have no affiliation or financial involvement with organizations or entities with a direct financial interest in the subject matter or materials discussed in this article. 


\section{References}

1 Motalleb G, Gholipour N, Samaei MN: Association of the human astrocyte elevated gene-1 promoter variants with susceptibility to hepatocellular carcinoma. Med Oncol 2014;31:916.

2 Napier Kyle J, Scheerer M, Misra S: Esophageal cancer: a review of epidemiology, pathogenesis, staging workup and treatment modalities. World J Gastrointest Oncol 2014;6:112-120.

-3 Gholipur C, Shalchi RA, Abbasi M: A histological study of esophageal cancer on the western side of the Caspian littoral from 1994 to 2003. Dis Esophagus 2008;21:322-327.

-4 Tran GD, Sun XD, Abnet CC, Fan JH, Dawsey SM, Dong ZW: Prospective study of risk factors for esophageal and gastric cancer in the Linxian general population trial chohort in China. Int J Cancer 2005;113:456-463.

$>5$ Kamangar F, Malekzadeh R, Dawsey SM, Saidi F: Esophageal cancer in Northeastern Iran: a review. Arch Iran Med 2007;10:70-82.

6 Haghdoost AA, Hosseini H, Chamani G, Zarei MR, Rad M, Hashemipoor M: Rising incidence of adenocarcinoma of the esophagus in Kerman, Iran. Arch Iran Med 2008;11:364-370.

7 Lam KY, Law S, Tin L, Tung PH, Wong J: The clinicopathological significance of p21 and p53 expression in esophageal squamous cell carcinoma: an analysis of 153 patients. Am J Gastroenterol 1999;94:2060-2068.

$>8$ Morisaki H, Ando A, Nagata Y, Pereira-Smith O, Smith JR, Ikeda K: Complex mechanisms underlying impaired activation of Cdk4 and Cdk2 in replicative senescence: roles of p16, p21, and cyclin D1. Exp Cell Res 1999;253: 503-510.

\$ Chang BD, Watanabe K, Broude EV, Fang J, Poole JC, Kalinichenko TV, Roninson IB: Effects of $p 21$ Waf1/Cip1/ Sdi1 on cellular gene expression: implications for carcinogenesis, senescence, and age-related diseases. Proc Natl Acad Sci USA 2000;97:4291-4296.

10 Shirakawa Y, Naomoto Y, Kimura M, Kawashima R, Yamatsuji T, Tamaki T: Topological analysis of $p 21$ WAF1/ CIP1 expression in esophageal squamous dysplasia. Clin Cancer Res 2000;6:541-550.

$\checkmark 11$ Zhu L, Harlow E, Dynlacht B: Dp107 uses a 21 CIP1-related domain to bind cyclin/cdk2 and regulate interactions with E2F. Genes Dev 1995;9:1740-1752.

12 Besson A, Dowdy SF, Roberts JM: CDK inhibitors: cell cycle regulators and beyond. Dev Cell 2008;14:159-169.

13 Tetsu 0, McCormick F: Proliferation of cancer cells despite CDK2 inhibition. Can Cell 2003;3:233-245.

14 Caffo O, Doglioni C, Veronese S, Bonzanini M, Marchetti A, Buttitta F: Prognostic value of $p 21$ (WAF1) and p53 expression in breast carcinoma: an immunohistochemical study in 261 patients with long-term follow-up. Clin Cancer Res 1996;2:1591-1599.

$>15$ Holm R, Skovlund E, Skomedal H, Florenes VA, Tanum G: Reduced expression of $p 21$ WAF1 is an indicator of malignant behaviour in anal carcinomas. Histopathol 2001;39:43-49.

16 Migaldi M, Sgambato A, Garagnani L: Loss of p21Waf1 expression is a strong predictor of reduced survival in primary superficial bladder cancers. Clin Cancer Res 2000;6:3131-3138.

-17 Schmider A, Gee C, Friedmann W, Lukas JJ, Press MF, Lichtenegger W, Reles A: p21 (WAF1/CIP1) protein expression is associated with prolonged survival but not with $p 53$ expression in epithelial ovarian carcinoma. Gynecol Oncol 2000;77:237-242.

18 Taghavi N, Biramijamal F, Abbaszadegan MR, Khademi H, Sotoudeh M, Khoshbakht S: p21 (waf1/cip1) gene polymorphisms and possible interaction with cigarette smoking in esophageal squamous cell carcinoma in northeastern Iran: a preliminary study. Arch Iran Med 2010;13:235-242.

19 Taghavi N, Biramijamal F, Sotoudeh M, Moaven O, Khademi H, Abbaszadegan MR, et al: Association of $p 53 / p 21$ expression with cigarette smoking and prognosis in esophageal squamous cell carcinoma patients. World J Gastroenterol 2010;16:4958-4967.

20 John SP, Chin CR, Perreira JM, Feeley EM, Aker AM, Savidis G, Smith SE, Elia AE, Everitt AR, Vora M: The CD225 domain of IFITM3 is required for both IFITM protein association and inhibition of influenza A virus and dengue virus replication. J Virol 2013;87:7837-7852.

-21 Liu ZM, Huang HS: As203-induced c-Src/EGFR/ERK signaling is via Sp1 binding sites to stimulate p21WAF1/ CIP1 expression in human epidermoid carcinoma A431 cells. Cell Signal 2006;18:244-255.

-22 Villwock MM, Meurer L, Cavazzola LT, Gurski RR, Edelweiss MI, Schirmer CC: Prevalence of p21 immunohistochemical expression in esophageal adenocarcinoma. Arq Gastroenterol 2006;43:212-218.

23 Abbas T, Dutta A: p21 in cancer: intricate networks and multiple activities. Nat Rev Cancer 2009;9:400-414.

-24 Bahl R, Arora S, Nath N, Mathur M, Shukla NK, Ralhan R: Novel polymorphism in p21 (waf1/cip1) cyclin dependent kinase inhibitor gene: association with human esophageal cancer. Oncogene 2000;19:323-328.

25 Khalili M, Eslami M, Masoumi P: Immunohistochemical evaluation of p21 and cyclin D1 expression in ameloblastoma of the jaws. JDM 2007;20:33-40.

26 Syngal S, Clarke G, Bandipalliam P: Potential roles of genetic biomarkers in colorectal cancer chemoprevention. J Cell Biochem 2000;34:28-34.

27 Booth RA: Minimally invasive biomarkers for detection and staging of colorectal cancer. Cancer Lett 2007;249: 87-96.

28 Ogino S, Kawasaki T, Kirkner GJ, Ogawa A, Dorfman I, Loda M: Downregulation of p21(CDKN1A/cip1) is inversely associated with microsatellite instability and CPG island methylator phenotype in colorectal cancer. J Pathol 2006;210:147-154.

-29 Pasz-Walczak G, Kordek R, Faflik M: p21 expression in colorectal cancer: correlation with p53 and cyclin D1 expression, clinicopathological parameters and prognosis. Pathol Res Pract 2001;197:683-689. 
-30 Casson AG, Tammemagi M, Eskandarian S: p53 alterations in oesophageal cancer: association with clinicopathological features, risk factors, and survival. Mol Pathol 1998;51:71-79.

-31 Casey G, Lopez ME, Ramos JC: DNA sequence analysis of exon 2 through 11 and immunohistochemical staining are required to detect all known p53 proliferations in human malignancies. Oncogene 1996;13:1971-1981.

-32 O'Reilly MA: Redox activation of p21 Cip1/WAF1/Sdi1: a multifunctional regulator of cell survival and death. Antioxid Redox Signal 2005;7:108-118.

-33 Zhou BP, Liao Y, Xia W, Spohn B, Lee MH, Hung MC: Cytoplasmic localization of p21 Cip1/WAF1 by Akt-induced phosphorylation in HER-2/neu-overexpressing cells. Nat Cell Biol 2001;3:245-252.

-34 Winters ZE, Leek RD, Bradburn MJ, Norbury CJ, Harris AL: Cytoplasmic p21 WAF1/CIP1 expression is correlated with HER-2/neu in breast cancer and is an independent predictor of prognosis. Breast Cancer Res 2003; 5:242-249.

-35 Ping B, He X, Xia W, Lee D-F, Wei Y, Yu D: Cytoplasmic expression of p21 CIP1/WAF1 is correlated with IKK overexpression in human breast cancers. Int J Oncol 2006;29:1103-1110.

-36 Dominguez-Sola D, Ying CY, Grandori C, Ruggiero L, Chen B, Li M: Non-transcriptional control of DNA replication by c-Myc. Nature 2007;448:445-451.

-37 Mukherjee S, Conrad S: c-Myc suppresses p21 WAF1/CIP1 expression during estrogen signaling and antiestrogen resistance in human breast cancer cells. J Biol Chem 2005;280:17617-17625.

38 Jung P, Menssen A, Mayr D, Hermeking H: AP4 encodes a c-MYC-inducible repressor of p21. Proc Natl Acad Sci USA 2008;105:15046-15051.

-39 Siegel PM, Massagué J: Cytostatic and apoptotic actions of TGF-beta in homeostasis and cancer. Nat Rev Cancer 2003;3:807-821.

40 Petrocca F, Visone R, Onelli MR, Shah MH, Nicoloso MS, de Martino I: E2F1-regulated microRNAs impair TGF 3 dependent cell-cycle arrest and apoptosis in gastric cancer. Cancer Cell 2008;13:272-286.

-41 Gartel AL, Shchors K: Mechanisms of c-myc-mediated transcriptional repression of growth arrest genes. Exp Cell Res 2003;283:17-21.

-42 Hwang-Verslues WW, Sladek FM: Nuclear receptor hepatocyte nuclear factor $4 \alpha 1$ competes with oncoprotein c-Myc for control of the p21/WAF1 promoter. Mol Endocrinol 2008;22:78-90.

43 Brenner C, Deplus R, Didelot C, Loriot A, Viré E, Smet Ch De: Myc represses transcription through recruitment of DNA methyltransferase corepressor. EMBO J 2005;24:336-346.

44 El Deiry WS, Tokino T, Velculescu VE, Levy DB, Parsons R, Trent JM: WAF1, a potential mediator of p53 tumor suppression. Cell 1993;75:817-825.

45 Deng C, Zhang P, Harper JW, Elledge SJ, Leder P: Mice lacking p21 CIP1/WAF1 undergo normal development, but are defective in G1 checkpoint control. Cell 1995;82:675-684.

46 Brugarolas J, Chandrasekaran CH, Gordon J, Beach D, Jacks T, Hannon GJ: Radiation-induced cell cycle arrest compromised by p21 deficiency. Nature 1995;377:552-557.

47 Efeyan A, Collado M, Velasco-Miguel S, Serrano M: Genetic dissection of the role of p21Cip1/Waf1 in p53-mediated tumour suppression. Oncogene 2007;26:1645-1649.

48 Barboza JA, Liu G, Ju Z, El-Naggar AK, Lozano G: p21 delays tumor onset by preservation of chromosomal stability. Proc Natl Acad Sci USA 2006;103:19842-19847.

49 Martin-Caballero J, Flores JM, Garcia-Palencia P, Serrano M: Tumor susceptibility of p21 Waf1/Cip1-deficient mice. Cancer Res 2001;61:6234-6238.

-50 Jacks T, Remington L, Williams BO, Schmitt EM, Halachmi S, Bronson RT: Tumor spectrum analysis in p53mutant mice. Curr Biol 1994;4:1-7.

51 Serrano M, Lee H, Chin L, Cordon-Cardo C, Beach D, DePinho RA: Role of the INK4a locus in tumor suppression and cell mortality. Cell 1996;85:27-37.

52 Kamijo T, Van de Kamp E, Randle DH, Sherr CJ: Tumor spectrum in ARF-deficient mice. Cancer Res 1999;59: 2217-2222.

53 Shiohara M, El-Deiry W, Wada M, Nakamaki T, Takeuchi S, Yang R: Absence of WAF1 mutations in a variety of human malignancies. Blood 1994;84:3781-3784.

-54 Patino-Garcia A, Sotillo-Pineiro E, Sierrasesumaga-Ariznabarreta L: p21/WAF1 mutation is not a predominant alteration in pediatric bone tumors. Pediatr Res 1998;43:393-395.

55 Forster K, Obermeier A, Mitina O, Simon N, Warmuth M, Krause G: Role of p21WAF1/CIP1 as an attenuator of both proliferative and drug-induced apoptotic signals in BCR-ABL-transformed hematopoietic cells. Ann Hematol 2008;87:183-193.

56 Gartel AL, Tyner AL: Transcriptional regulation of the p21 WAF1/CIP1 gene. Exp Cell Res 1999;246:280-289.

57 Hiyama H, Iavarone A, Reeves SA: Regulation of the cdk inhibitor $p 21$ gene during cell cycle progression is under the control of the transcription factor E2F. Oncogene 1998;16:1513-1523.

58 Woods D, Parry D, Cherwinski H, Bosch E, Lees E, McMahon M: Raf-induced proliferation or cell cycle arrest is determined by the level of Raf activity with arrest mediated by p21 Cip1. Mol Cell Biol 1997;17:5598-5611.

59 Collado M, Blasco MA, Serrano M: Cellular senescence in cancer and aging. Cell 2007;130:223-233.

60 Adnane J, Jackson RJ, Nicosia SV, Cantor AB, Pledger WJ, Sebti SM: Loss of p21 WAF1/CIP1 accelerates Ras oncogenesis in a transgenic/knockout mammary cancer model. Oncogene 2000;19:5338-5347.

61 Missero C, Di Cunto F, Kiyokawa H, Koff A, Dotto GP: The absence of p21 Cip1/WAF1 alters keratinocyte growth and differentiation and promotes ras-tumor progression. Genes Dev 1996;10:3065-3075. 
-62 Swarbrick A, Roy E, Allen T, Bishop JM: Id1 cooperates with oncogenic Ras to induce metastatic mammary carcinoma by subversion of the cellular senescence response. Proc Natl Acad Sci USA 2008;105:5402-5407.

63 Xu C, Meikrantz W, Schlegel R, Sager R: The human papilloma virus 16E6 gene sensitizes human mammary epithelial cells to apoptosis induced by DNA damage. Proc Natl Acad Sci USA 1995;92:7829-7833.

64 Burkhart BA, Alcorta DA, Chiao C, Isaacs JS, Barrett JC: Two posttranscriptional pathways that regulate p21 Cip1/Waf1/Sdi1 are identified by HPV16-E6 interaction and correlate with life span and cellular senescence. Exp Cell Res 1999;247:168-175.

65 Finzer P, Aguilar-Lemarroy A, Rosl F: The role of human papillomavirus oncoproteins E6 and E7 in apoptosis. Cancer Lett 2002;188:15-24.

66 Alam S, Sen E, Brashear H, Meyers C: Adeno-associated virus type 2 increases proteosome dependent degradation of p21 WAF1 in a human papillomavirus type 31b-positive cervical carcinoma line. J Virol 2006;80: 4927-4939.

-67 Yoshida I, Oka K, Hidajat R, Nagano-Fujii M, Ishido S, Hotta H: Inhibition of p21/Waf1/Cip1/Sdi1 expression by hepatitis C virus core protein. Microbiol Immunol 2001;45:689-697.

68 Jarviluoma A, Child ES, Sarek G, Sirimongkolkasem P, Peters G, Ojala PM: Phosphorylation of the cyclindependent kinase inhibitor p21 Cip1 on serine 130 is essential for viral cyclin-mediated bypass of a p21 Cip1imposed G1 arrest. Mol Cell Biol 2006;26:2430-2440.

69 Shen KC, Heng H, Wang Y, Lu S, Liu G, Deng CX, Brooks SC, Wang YA: ATM and p21 cooperate to suppress aneuploidy and subsequent tumor development. Cancer Res 2005;65:8747-8753.

70 Topley G, Okuyama R, Gonzales J, Conti C, Dotto GP: p21 WAF1/Cip1 functions as a suppressor of malignant skin tumor formation and a determinant of keratinocyte stem-cell potential. Proc Natl Acad Sci USA 1999;96: 9089-9094.

71 Philipp J, VO K, Gurley KE, Seidel K, Kemp CJ: Tumor suppression by p27Kip1 and p21 Cip1 during chemically induced skin carcinogenesis. Oncogene 1999;18:4689-4698.

72 Braun SE, Mantel C, Rosenthal M, Cooper S, Liu L, Robertson KA: A positive effect of p21 cip1/waf1 in the colony formation from murine myeloid progenitor cells as assessed by retroviral-mediated gene transfer. Blood Cells Mol Dis 1998;24:138-148.

73 Viale A, De Franco F, Orleth A, Cambiaghi V, Giuliani V, Bossi D: Cell-cycle restriction limits DNA damage and maintains self-renewal of leukaemia stem cells. Nature 2009;457:51-56.

-74 Jaiswal PK, Singh V, Mittal RD: Polymorphism at p21 codon 31 and dinucleotide polymorphism of P73 gene and susceptibility to bladder cancer in individuals from North India. Indian J Hum Genet 2013;19:293-300.

75 Liu Y, Yeh N, Zhu X-H, Leversha M, Cordon-Cardo C, Ghossein R: Somatic cell type specific gene transfer reveals a tumor-promoting function for p21 Waf1/Cip1. EMBO J 2007;26:4683-4693.

76 Ishida M, Morita M, Saeki H, Ohga T, Sadanaga N, Watanabe M: Expression of p53 and p21 and the clinical response for hyperthermochemoradiotherapy in patients with squamous cell carcinoma of the esophagus. Anticancer Res 2007;27:3501-3506.

77 Ouyang XS, Wang X, Ling MT, Wong HL, Tsao SW, Wong YC: Id-1 stimulates serum independent prostate cancer cell proliferation through inactivation of p16(INK4a)/pRB pathway. Carcinogenesis 2002;23:721725.

-78 Schoppmann SF, Schindl M, Bayer G, Aumayr K, Dienes J, Horvat R: Overexpression of Id-1 is associated with poor clinical outcome in node negative breast cancer. Int J Cancer 2003;104:677-682.

79 Edmonston TB, Cuesta KH, Burkholder S, Barusevicius A, Rose D, Kovatich AJ: Colorectal carcinomas with high microsatellite instability: defining a distinct immunologic and molecular entity with respect to prognostic markers. Hum Pathol 2000;31:1506-1514.

80 Jahantigh M, Narooi B, Shakhi E, Davarian A: Prevalence of p53 and p21 expression in colorectal cancer: a histopathologic study from Iran. J Biol Sci 2012;12:327-331.

81 Weinberg W, Fernandez-Salas E, Morgan D, Shalizi A, Mirosh E, Stanulis E, Deng C, Hennings H, Yuspa SH: Genetic deletion of p21WAF1 enhances papilloma formation but not malignant conversion in experimental mouse skin carcinogenesis. Cancer Res 1999;59:2050-2054.

82 Sassano A, Platanias LC: Statins in tumor suppression. Cancer Lett 2008;260:11-19.

83 Wu CH, Riggelen J, Yetil AC, Fan A, Bachireddy PW, Felsher D: Cellular senescence is an important mechanism of tumor regression upon c-Myc inactivation. Proc Natl Acad Sci USA 2007;104:13028-13033.

-84 Cindy J, Smith A, Osborn M: Advantages and limitations of quantitative PCR(Q-PCR)-based approaches in microbial ecology. Microbiol Ecol 2009;67:6-20. 